\title{
Changing beta-blockers in heart failure: when is a class not a class?
}

Are all the drugs in a class the same? Take the COX-2 inhibitors, for example. Rofecoxib increases the risk of a heart attack or stroke; but do other COX-2 inhibitors, such as celecoxib, do likewise? In other words, is this adverse effect of rofecoxib a class effect? The concept of grouping compounds in classes is useful, because it prompts questions regarding their similarities and differences. But what makes a class?

The short answer is that drug class is best defined by the most important attribute of a drug: its main pharmacological target of action. Because the target is so important, the terms 'on-target' and 'off-target', originally invented in the context of drug discovery, are sometimes used to differentiate drug actions. However, in colloquial parlance not all drug classes are named according to their target, even in the World Health Organization's Anatomical Therapeutic and Chemical (ATC) drug classification system ${ }^{1}$ (Table 1). The idea of a class of drugs, even when it is based on the pharmacological target, is one that does not always bear close scrutiny, for several reasons.

Firstly, the main pharmacological target may not be known. Secondly, some classes of drugs, such as monoclonal antibodies, have no common target, although they may have some effects in common, such as adverse effects. Thirdly, some drugs have more than one main target: spironolactone, for example, is an antagonist at aldosterone receptors through its active metabolite canrenone, which is why it is a potassium-sparing diuretic, but it also has an antiandrogenic action, which is why it causes gynaecomastia and is used to treat polycystic ovary syndrome.

Table 1. Origins of the colloquial names of some classes of drugs.

\begin{tabular}{llll}
$\begin{array}{l}\text { Colloquial } \\
\text { class name }\end{array}$ & Origin of name & $\begin{array}{l}\text { Main pharmacological } \\
\text { target }\end{array}$ & $\begin{array}{l}\text { ATC description } \\
\text { (code) }\end{array}$ \\
\hline $\begin{array}{l}\text { Aminoglycoside } \\
\text { antibiotics }\end{array}$ & $\begin{array}{l}\text { Chemical structure } \\
\text { and general action }\end{array}$ & $\begin{array}{l}\text { Inhibition of bacterial } \\
\text { ribosomal protein } \\
\text { synthesis }\end{array}$ & $\begin{array}{l}\text { Aminoglycoside } \\
\text { antibacterials } \\
\text { (J01G) }\end{array}$ \\
\hline $\begin{array}{l}\text { Cardiac glycosides; } \\
\text { digitalis }\end{array}$ & $\begin{array}{l}\text { Target organ and } \\
\text { chemical structure; } \\
\text { plant of origin }\end{array}$ & $\begin{array}{l}\text { Inhibition of } \\
\text { Na/K-ATPase }\end{array}$ & $\begin{array}{l}\text { Cardiac glycosides } \\
\text { (C01A) }\end{array}$ \\
\hline $\begin{array}{l}\text { Loop diuretics } \\
\text { Target structure } \\
\text { and general action }\end{array}$ & Inhibition of Na/K/Cl & co-transport & $\begin{array}{l}\text { High-ceiling diuretics } \\
\text { (C03C) }\end{array}$ \\
\hline Monoclonal antibodies & $\begin{array}{l}\text { Method of synthesis } \\
\text { and general action }\end{array}$ & [Various] & $\begin{array}{l}\text { Monoclonal } \\
\text { antibodies (L01XC) }\end{array}$ \\
\hline $\begin{array}{l}\text { Non-steroidal } \\
\text { anti-inflammatory } \\
\text { drugs }\end{array}$ & $\begin{array}{l}\text { [Non-]structure and } \\
\text { general action }\end{array}$ & $\begin{array}{l}\text { Inhibition of } \\
\text { cyclo-oxygenase }\end{array}$ & $\begin{array}{l}\text { Anti-inflammatory and } \\
\text { antirheumatic products, } \\
\text { non-steroids (M010) }\end{array}$ \\
\hline Penicillins & $\begin{array}{l}\text { Source } \\
\text { Inhibition of bacterial }\end{array}$ & $\begin{array}{l}\text { Beta-lactam } \\
\text { antibacterials, } \\
\text { penicillins (J01C) }\end{array}$ \\
\hline $\begin{array}{l}\text { Potassium-sparing } \\
\text { diuretics }\end{array}$ & $\begin{array}{l}\text { Lack of adverse effect } \\
\text { and general action }\end{array}$ & [Various] & $\begin{array}{l}\text { Potassium-sparing } \\
\text { agents (C03D) }\end{array}$ \\
\hline Statins & $\begin{array}{l}\text { Non-proprietary names } \\
\text { (signifying 'enzyme } \\
\text { inhibitors') }\end{array}$ & $\begin{array}{l}\text { Inhibition of HMG CoA } \\
\text { reductase }\end{array}$ & $\begin{array}{l}\text { HMG CoA reductase } \\
\text { inhibitors (C10AA) }\end{array}$ \\
\hline ATC = Anatomical, Therapeutic, and Chemical. & & \\
\hline
\end{tabular}

Even if a single main target can be identified, drugs within a class often have actions on more than one subsidiary target. Tricyclic antidepressants, with a therapeutic action probably due to inhibition of presynaptic monoamine reuptake, have adverse effects that are mediated by anticholinergic effects and inhibition of cardiac potassium channels.

Diversity of this kind within a class can arise through pharmacokinetic or pharmacodynamic differences - from the molecule itself, from active metabolites, or from stereoisomers. Physicochemical properties can affect tissue distribution: lipophilic antihistamines enter the brain more readily than hydrophilic ones and cause sedation.

Some statins are metabolized by the enzyme CYP3A4 and interact with compounds such as erythromycin, itraconazole, ritonavir, and grapefruit juice, but fluvastatin is metabolized by CYP2C9 and pravastatin and rosuvastatin are eliminated unchanged. Among the phenothiazines, chlorpromazine is not only an antagonist at dopamine receptors, it also has anticholinergic, antiadrenergic, antihistaminic, and antiserotonergic actions, due in part to its many active metabolites, and not for nothing has it been called Largactil ${ }^{\circledR}$ (from the French large activité [Sanofi-Aventis]); other phenothiazines do not share these properties. Several beta-blockers have more than one action because of stereoisomers; labetalol, for example, has two chiral centres in its structure and is both an alpha-blocker and a betablocker.

In this issue of the BJGP, Mant et a/ report that in patients with congestive cardiac failure, a switch to bisoprolol or carvedilol, in most cases from atenolol, had the most significant beneficial effect on the plasma concentration of B-type natriuretic peptide (BNP), which is a measure of the degree of ventricular 
dysfunction and a strong predictor of death. This should come as no surprise, as the range of actions of which betablockers are capable is wide, and there are significant differences from betablocker to beta-blocker. ${ }^{3,4}$ The differences in the actions of some beta-blockers are shown in Table 2 under five headings: lipophilicity, cardioselectivity, partial agonist activity, membrane stabilizing activity, and vasodilatation. ${ }^{5}$ Much of this information comes from in vitro experiments or experiments in animals.

\section{LIPOPHILICITY}

Beta-blockers that are more lipophilic are extensively metabolized in the gut wall and liver (first-pass metabolism). This first-pass clearance is variable and can result in twenty-fold differences in plasma drug concentrations among patients who have taken the same dose. It also produces susceptibility to interactions with drugs that alter hepatic drug metabolism, for example cimetidine, and can result in altered pharmacokinetics and hence drug response in patients with liver disease, particularly cirrhosis.

It has been suggested that lipophilic beta-blockers are more likely to be associated with reduced mortality and sudden cardiac death after myocardial infarction and in congestive heart failure. ${ }^{6}$ They also enter the brain more readily and are more likely to cause adverse nervous system effects, such as sleep disturbances. ${ }^{7}$

\section{CARDIOSELECTIVITY}

Relatively cardioselective betaadrenoceptor $\left(\beta_{1}\right)$ antagonists, such as atenolol and metoprolol, offer theoretical advantages over non-selective drugs in patients with bronchial asthma and peripheral vascular disease, as bronchioles and peripheral blood vessels contain principally $\beta_{2}$ adrenoceptors. In practice, the degree of selectivity in the individual is not predictable enough to make these differences very useful; it is better to avoid all beta-blockers in such patients, if possible. In diabetes mellitus, non-selective beta-blockers mask the peripheral symptoms of acute hypoglycaemia more than the $\beta_{1}$ selective drugs.

\section{PARTIAL AGONIST ACTIVITY}

Partial agonist activity is the property whereby a molecule that occupies betaadrenoceptors has agonist (stimulatory) effects of its own while competitively inhibiting the effects of other agonists. The effects of partial beta-agonists depend on the degree of endogenous tone of the sympathetic nervous system: when there is high endogenous sympathetic tone they tend to act as beta-antagonists (betablockers); when endogenous sympathetic tone is low they tend to act as betaagonists (beta-stimulants). This can be important; for example, xamoterol, a $\beta_{1}$ selective drug, was specifically designed with a very precise balance of partial agonism (about 45\%) to be of value in heart failure; however, it caused deterioration in patients with severe heart failure (New York Heart Association Functional Classification grades III and IV). ${ }^{8}$

\section{MEMBRANE-STABILIZING ACTIVITY}

Beta-blockers with membrane-stabilizing activity reduce the rate of rise of the cardiac action potential and have other electrophysiological effects. However, membrane-stabilizing activity occurs only at very high concentrations and is not of clinical relevance, except after a large overdose.

\section{VASODILATATION}

Vasodilating properties can arise from more than one action. ${ }^{9,10}$ Some betablockers combine $\beta_{1}$ antagonism or partial agonism with $\beta_{2}$ agonism (celiprolol, dilevalol, labetalol, pindolol) or with alpha antagonism (carvedilol, labetalol ${ }^{11}$ ). Both of these subclasses have significant peripheral vasodilating effects. In contrast, drugs with significant agonist activity at $\beta_{1}$ adrenoceptors have poor antihypertensive properties. Nebivolol causes vasodilatation through a mechanism involving nitric oxide. ${ }^{12}$ Betablockers that are used to treat glaucoma (betaxolol, carteolol, levobunolol, and timolol) cause vasodilatation in ocular blood vessels by blocking voltagesensitive calcium channels. ${ }^{13,14}$ The beneficial effects of bisoprolol and carvedilol on plasma BNP concentrations compared with atenolol are probably due to relative vasodilatation.

\section{CONCLUSION}

Although the concept of class effect can be useful in identifying drugs that are likely to have similar actions, one should never assume that the members of a class will have exactly the same effects as each other: beta-blockers certainly do not. Different members of the class have different actions, both beneficial and harmful, in different patients. The current evidence suggests that in patients with heart failure who need a beta-blocker, drugs such as bisoprolol or carvedilol are probably to be preferred to atenolol.
Table 2. Differences in the actions of some beta-blockers.

\begin{tabular}{|c|c|c|c|c|c|}
\hline Drug & $\begin{array}{l}\text { Lipid } \\
\text { solubility }\end{array}$ & $\begin{array}{l}\text { Cardio- } \\
\text { selectivity }\end{array}$ & $\begin{array}{l}\text { Partial } \\
\text { agonist } \\
\text { activity }\end{array}$ & $\begin{array}{l}\text { Membrane- } \\
\text { stabilizing } \\
\text { activity }\end{array}$ & $\begin{array}{l}\text { Peripheral } \\
\text { vasodilatation }\end{array}$ \\
\hline Atenolol & - & + & - & - & - \\
\hline Bisoprolol & + & +++ & - & - & + \\
\hline Carvedilol & +++ & - & - & ++ & ++ \\
\hline Labetalol & + & - & - & \pm & ++ \\
\hline Metoprolol & + & + & - & \pm & + \\
\hline Oxprenolol & + & - & + & + & - \\
\hline Practolol & - & ++ & + & - & - \\
\hline Propranolol & ++ & - & - & ++ & \pm \\
\hline Sotalol & - & - & - & - & - \\
\hline Timolol & + & - & \pm & \pm & + \\
\hline
\end{tabular}




\section{Jeffrey K Aronson,}

Reader in Clinical Pharmacology, Department of Primary Health Care, University of Oxford

\section{REFERENCES}

1. WHO Collaborating Centre for Drug Statistics Methodology. Complete ATC/DDD Index 2008. http://www.whocc.no/atcddd (accessed 30 Apr 2008).

2. Mant D, Hobbs FDR, Glasziou P. Identification and guided treatment of ventricular dysfunction in general practice using blood B-type natriuretic peptide. $\mathrm{Br}$ Gen Pract 2008; 58: 393-399.

3. Kendall MJ. Clinical relevance of pharmacokinetic differences between beta blockers. Am J Cardiol 1997; 80(9B): 15J-19J.

4. Van Zwieten PA. Comparative properties of various beta-blockers, with an outlook to the future. Clin Physiol Biochem 1990; 8 Suppl 2: 18-27.

5. Lim PO, MacDonald TM, Magrioni AP, et al. Betaadrenoceptor antagonists. In: Aronson JK (ed.). Meyler's side effects of drugs: the international encyclopedia of adverse drug reactions and interactions. Amsterdam: Elsevier, 2006: 452-478.

6. Hjalmarson A. Cardioprotection with betaadrenoceptor blockers. Does lipophilicity matter? Basic Res Cardiol 2000; 95 Suppl 1: I41-45.
7. Betts TA, Alford C. Beta-blockers and sleep: controlled trial. Eur J Clin Pharmacol 1985; 28 Suppl: $65-68$.

8. Cruickshank JM. The xamoterol experience in the treatment of heart failure. Am J Cardiol 1993; 71(9): 61C-64C.

9. Tsukiyama H, Otsuka K, Horii M, et al. Possible significance of the pharmacological differentiation of beta-blocking agents in hemodynamic effects in essential hypertension. Jpn Circ J 1983; 47(3): 313-322.

10. Pedersen ME, Cockcroft JR. The vasodilatory betablockers. Curr Hypertens Rep 2007; 9(4): 269-277.

11. Van Zwieten PA. An overview of the pharmacodynamic properties and therapeutic potential of combined alpha- and beta-adrenoceptor antagonists. Drugs 1993; 45(4): 509-517.

12. Sule SS, Frishman W. Nebivolol: new therapy update. Cardiol Rev 2006; 14(5): 259-264.

13. Wu KY, Wang HZ, Hong SJ. Inhibition of endothelinand $\mathrm{KCl}$-induced increase of $\left[\mathrm{Ca}^{2+}\right]_{\mathrm{i}}$ by antiglaucoma drugs in cultured A7r5 vascular smooth-muscle cells. Ocul Pharmacol Ther 2004; 20(3): 201-209.

14. Dong Y, Ishikawa H, Wu Y, Yoshitomi T. Vasodilatory mechanism of levobunolol on vascular smooth muscle cells. Exp Eye Res 2007; 84(6): 1039-1046.

DOI: 10.3399/bjgp08X299317

\section{Competing interests}

Potential conflict of interest: Jeffrey K Aronson is a member of the Department of Primary Health Care in Oxford, where the work by Mant et al was carried out; he did not take part in that work and was commissioned by the British Journal of General Practice to write an explanatory commentary on the mechanistic interpretation of the results.

\section{ADDRESS FOR CORRESPONDENCE:}

\section{JK Aronson,}

University Department of Primary Health

Care, Rosemary Rue Building, Old Road

Campus, Headington, Oxford OX3 7LF

E-mail: jeffrey.aronson@clinpharm.ox.ac.uk

Discuss these editorials. Contribute and read comments about these editorials on the Discussion Forum: http://www.rcgp.org.uk/bjgp-discuss 